\title{
Implementation of human development policy in health sector in decentralization perspective
}

\author{
Genta Rizkyansah, Ety Rahayu
}

Department of Social Welfare, Universitas Indonesia, Indonesia

\begin{tabular}{|c|c|}
\hline Article Info & ABSTRACT \\
\hline Article history: & \multirow{10}{*}{$\begin{array}{l}\text { The high case of malaria and dengue hemorrhagic fever (DHF) in Indonesia } \\
\text { is resolved by government of the Republic of Indonesia through human } \\
\text { development policies in health sector. This policy is implemented through } \\
\text { the Indonesian health program with family approach. One of the goals of } \\
\text { Indonesian health program with family approaches is a disease control. This } \\
\text { was descriptive qualitative research to describe the implementation of human } \\
\text { development policies in health sector through the Indonesian health program } \\
\text { with family approach and to confirm the obstacles in the implementation of } \\
\text { intended policy. The results showed that the communication factor is carried } \\
\text { out through policy socialization and focus group discussion. The disposition } \\
\text { factor is carried out by providing technical support in the form of regulations } \\
\text { and intensive provision to health personnel. The bureaucratic structure factor } \\
\text { is indicated by the division of tasks and functions of each organization } \\
\text { involved. The resource is a factor that becomes an obstacle in policy } \\
\text { implementation. Lack of staff and budget are the reasons of program does not } \\
\text { run optimally. }\end{array}$} \\
\hline Received Dec 3, 2020 & \\
\hline Revised Feb 20, 2021 & \\
\hline Accepted Mar 11, 2021 & \\
\hline Keywords: & \\
\hline Desentralization & \\
\hline Health sector & \\
\hline Human development & \\
\hline Implementation & \\
\hline Policy & \\
\hline
\end{tabular}

This is an open access article under the CC BY-SA license.

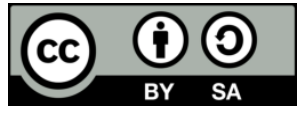

\section{Corresponding Author:}

Genta Rizkyansah

Department of Social Welfare, Faculty of Social and Political Sciences

Universitas Indonesia

Depok, West Java - 16424, Indonesia

Email: gentarizkyansah@gmail.com

\section{INTRODUCTION}

In Indonesia, morbidity and mortality due to disease are indicators in assessing the degree of public health. In 2012 the success rate of tuberculosis treatment is $83.7 \%$, decreasing to $82.8 \%$ in 2013 , dengue hemorrhagic fever (DHF) sufferers were 37.27, increasing to 45.85 in 2013 and the mosquito larva-free rate in Indonesia until 2013 is $80.09 \%$ and this figure has not reached the government's target of $>95 \%$ [1]. Then, in 2015 , the malaria morbidity rate from $2005-2013$ is 1.38 per 1,000 population and it has not yet reached the government's target of $<1.25$ per 1,000 population and malaria-free areas in Indonesia are $21.5 \%$, increasing to $45.4 \%$ in 2015 [2]. Furthermore, the prevalence of stunting in 2010 is 35.6\%, increasing to $37.2 \%$ in 2013 [3]. The data show that there are still many health problems in Indonesia. These health problems can contribute to the low human development index in Indonesia. To solve these various health problems, president of Indonesia has a vision that is described in "nawacita" (nine hopes). One of the content ideas of "nawacita" is to improve the quality of life of the Indonesian people [4].

The efforts to improve the quality of life of Indonesians in the health sector are carried out through the Indonesian health program with a family approach [4]. In 2015-2019, the health budget is increased and that health budget is allocated for several things, including stunting prevalence, tuberculosis prevalence, malaria case treatment in 300 regencies/cities through the implementation of the Indonesian 
health program [5]. The Indonesian Health Program is used as part of the Ministry of Health's strategic plan 2015-2019 which is enacted through the Decree of the Minister of Health of the Republic of Indonesia Number HK.02.02/ Menkes/52/2015 [6]. The Indonesian health program is a human development policy instrument implemented with a top-down approach to address health problems in Indonesia. This top-down approach is implemented with local governments as the subordinate of central government. This approach uses the principle of decentralization. Currently, many developing countries, including Indonesia, are practicing decentralized government systems. This is a positive governmental improvement because decentralization is closely related to democracy, political reform, community participation, empowerment, economic development, accountability and is an increase of human resource capacity [7]. In this study, increasing human resources is carried out through human development policies in the health sector. The health sector in this study is chosen because health services are basic services for every citizen and have now become the part of the millennium development goals (MDG's) which exist as a mean through which the government conduct an effort to implement and to succeed in transforming the lives of its citizens in all aspects of human aspect [8].

Several recent studies about policy implementation in the health sector have been conducted by researchers, including Agustina's research focusing on the implementation of the Indonesian health program with a family approach using contract workers in Kulon Progo-Yogyakarta, Indonesia [9], Fatimah's research focused on the use of budget, facilities and infrastructure in the program implementation of Indonesian health program with a family approach (PIS-PK) in Barito Kuala-South Kalimantan [10], Rosalia's research focuses on the impact of decentralization on health services in Pesawaran Regency-Lampung Province [11], Uzhma's research focuses on people with mental disorders as beneficiaries of the Indonesian health program with the family approach in Semarang-Central Java [12].

Furthermore Alam's research focuses on the performance of the Indonesian health program officers with a family approach in the data collection phase in Semarang-Central Java [13], Roesli's research focuses on the preparation stage for the implementation of Indonesian health program with a family approach in Depok-Java Barat [14], Pujosiswanto's research focuses on the factors that influence the implementation of the Indonesian health program with a family approach in West Sulawesi-Indonesia [15], Karunianingsih's research focuses on the factors that influence the implementation of the Indonesian health card in SurakartaCentral Java [16], Astuti's research focuses on the readiness of financing the Indonesian health program with a family approach [17] and Riswandha's research focuses on the performance of the officers of the Indonesian health program with a family approach in Jember-East Java [18].

Based on some of these researches, this research has differences, including the overall research which generally only discusses one concept, namely between policy implementation or the influence factor of the policy implementation as a basis for conducting analysis, but there has not been a research that discusses the concept of policy implementation and the concept of integrated decentralization which is adjusted to focus in human development policies through the Indonesian health program with a family approach $(P I S-P K)$, the entire previous researches only focus on the preparation stage (data collection), the use of health personnel and specific targets such as people with mental disorders. This study shows that there has not been a comprehensive discussion regarding the stages of program implementation, especially disease control, the involvement of all stakeholders (across sectors) in programs and program targets at the family level (not individuals) and there has not been a research being found that discusses the health service process. The method of visiting beneficiaries' homes (door to door) and in general, previous studies use the service method by visiting health facilities such as public health center and hospitals. There are two reasons for the researchers to conduct this research, they are the location and policy. First, this policy is conducted in Pesawaran Regency, Lampung Province, as a new autonomous region and for several reasons it also has strong characteristics for this research such as the number of malaria and pulmonary tuberculosis cases is the highest compared to other new autonomous regions [19]. Pesawaran Regency is also the only new autonomous region in Lampung Province to receive a special allocation fund (DAK) for the health sector [20], however, disease cases in Pesawaran Regency are the highest compared to other new autonomous regions in Lampung Province. Second, the goal of the human development policies in the health sector is to overcome the health problems such as malaria and tuberculosis. This goal is achieved through the implementation of the Indonesian health program with a family approach. This study seeks to answer the research questions: How are the implementation of human development policies in the health sector in the perspective of decentralization in Pesawaran Regency, Lampung Province and what obstacles arise in implementing these policies. This research is expected to provide a theoretical contribution to the implementation of human development policies in the health sector from the perspective of decentralization in Indonesia, particularly in new autonomous regions. The results of this research can develop the disciplines of public policy and social welfare. 


\section{RESEARCH METHOD}

\subsection{Research design}

This research employed qualitative approach with descriptive research type. The descriptive research helps the researcher to describe things in detail and specifically from the situations and social backgrounds [21]. The results of descriptive research are to provide a detailed description of the problem or answer to the research question. Then, in analyzing the data, the researcher uses the policy implementation models in accordance with Edwards III theory which include communication, resources, dispositions and bureaucratic structures. Communication includes coordination regarding to the policy implementation. Resources include employees and facilities to support policy implementation. The disposition includes the duties and authorities and the bureaucratic structure includes the relationship between agencies in implementing policies including supervision [22].

\subsection{Research scope}

The scope of this research is focused on human development policies through the Indonesian health program with a family approach $(P I S-P K)$ as one of the programs which has the aim of controlling malaria. The research location is focused in Durian Village, Padang Cermin District, Pesawaran Regency, Lampung Province, Indonesia. The highest malaria cases in Padang Cermin District are in Durian Village and it has increased from 2014-2016, which is amounted to 136 cases in 2014, 152 cases in 2015 and 175 cases in 2016 [23].

\subsection{Data collection method}

To collect relevant data, the researchers use interview, observation and documentation methods [24]. Interviews are conducted to obtain an in-depth data from the conversations. Observations are conducted in Durian Village, Padang Cermin District and at Pesawaran Regency Health Office to obtain the data on the implementation of policies based on decentralization perspective. Documentation is focused on obtaining data on policy implementation which includes the standard operating procedures (SOP) and the guidelines of Indonesian health program with a family approach [25].

\subsection{Sampling method}

Informants are selected through purposive sampling method which is determined by certain criteria sampling [26]. Two policy regulators, two policy implementers and three policy beneficiaries. The regulator criteria are those who participate in policymaking and are able to explain policy. Criteria for policy implementers: staff implementing policies and criteria for beneficiaries: public who follow the policy implementation process in accordance with the standard operating procedure (SOP).

\subsection{Data analysis}

After obtaining the research data, the researchers analyze the data by using several analytical techniques. Data analysis techniques include open coding, selective coding and memo writing [27]. In this part, researchers select and process the data in a final report which consist of sorting, classification and coding.

\section{RESULTS AND DISCUSSION}

\subsection{Communication}

Implementing policies in order to achieve success requires that implementers know clearly what to do. Policy goals and objectives must be informed to the target group, so as to reduce the implementation distortions. In the context of this research, Pesawaran Regional government through the Health Office acts as the policy implementer to communicate to the beneficiaries of the Indonesian health program with a family approach $(P I S-P K)$. The communication is carried out with various methods such as socialization program, a visit to beneficiary homes (home care) and focus group discussions. For the results of the interviews with health personnel, it includes the result of the socialization which includes socialization of clean and healthy living habits, socialization of malaria and socialization of maternal and child health. A visit to beneficiaries are carried out routinely within one month with the contents of data collection activities for families who are sick, monitoring on bathing, washing and toilets $(M C K)$ and monitoring on nutrition for families with the children under five. Focus group discussions are held in January 2020 with participants from various elements such as the village officers, health personnel as program implementer, midwives, and members of the Village Council (BPD). The result of the focus group discussion is that the treatment of malaria in Durian Village, Padang Cermin District is carried out by distributing mosquito nets once in a year and by conducting a fogging. These various activities are carried out in accordance with the focus of Indonesian health program 
with a family approach in Padang Cermin District which is disease control. Then, the Ministry of Health as the policy maker, communicates with the local governments through socialization. In addition, to ensure the consistency of the policy objectives, the Ministry of Health undertakes coaching and monitoring efforts through the zoom meeting and is carried out once in three months. This shows that the communication carried out by policy makers and implementers has been effectiveCommunication can be called effective when the communicant is successful in conveying what he means. Effective communication can be determined by five things, namely understanding, feeling comfort, influencing attitudes, beliefs and taking actions [28]. This shows that the effective communication will have a direct or indirect effect on policy implementation. This shows that the communication carried out by the policy implementers in Indonesian health program with a family approach to beneficiaries is successful because the various elements involved in the program have the same goal which is controlling the malaria cases [22].

\subsection{Resources}

Resources are an important factor in policy implementation so that the policies can run effectively and efficiently. Without resources, policies are only documents that are not conducted to provide solution to problems that exist in society and to provide services to the public. In the context of this research, resources in the implementation of human development policies in health sector are the health personnel as policy implementers and Durian Village officers as the supervisor. The number of health personnel in Durian Village is one personnel and the number of program beneficiaries is 503 heads of families [29]. The number of health personnel and beneficiaries is incomparable. This problem shows that there is a shortage of officers who carry out the program (implementers). Based on interviews with the health personnel, there are very few resources to implement the Indonesian health program with a family approach in Durian Village and there is a need for additional health personnel. Currently, in implementing the program, health personnel assisted by village midwives and integrated health center (Posyandu) cadres. At the data collection part, health personnel experienced difficulties due to a lack of resources and the data collection time provided by the Health Office of Pesawaran Regency is only two weeks. Patient satisfaction and loyalty which are influenced by the quality of health facilities has been widely proven in research at first-level health facilities and advanced health facilities [30]. Inadequate health facilities in Durian Village, Padang Cermin District, Pesawaran Regency is certainly not in line with the results of this study and has an impact on the low satisfaction of beneficiary families. It then influences the loyalty of beneficiary families on regular participation in Indonesia health program with a family approach $(P I S-P K)$ activities and beneficiary families have a possibility to suggest other families not to participate in the program activities.

\subsection{Disposition}

A good implementer must have a good disposition, an implementer can carry out a policy properly in accordance with the planned objectives. Policy implementer support is very important so that policies can run well. The support in human development policies in health sector is provided by policy implementers in the form of technical regulations such as the Pesawaran Regent's Regulation Number 58 of 2018 concerning on the Indonesian health program with a family approach $(P I S-P K)$, technical guidelines and implementation guidelines for the Indonesian Health Program with a Family Approach $(P I S-P K)$ and the Durian Village Regulation. Another support is in the form of intensive provision to health personnel. Disposition affects the effectiveness of a policy. The higher the disposition is set, the more effective a policy will be [31]. In the context of this research, the disposition carried out by the local government has been good and based on the observations of the researchers, the disposition is carried out by the Regent of Pesawaran through the 2020 local government work program.

\subsection{Bureaucratic structure}

The bureaucratic structure is related to the organizational structure. The bureaucratic structure in the implementation of the Indonesian health program with family approach is hierarchical [22]. The Indonesian health program with a family approach $(P I S-P K)$ is under the coordination of the Ministry of Health through the Directorate General of Health Services. Then at the provincial and regional levels, The Indonesian health program with a family approach $(P I S-P K)$ is under the coordination of the Health Office. Technically, the implementation of The Indonesian health program with a family approach $(P I S-P K)$ is carried out at the district level through the technical implementation unit of the public health center, then health personnel provides the services to beneficiary families [32]. In the context of this research, there is a program implementer structure that has their respective duties and functions. Then, the local government has made the standard operating procedures (SOP) and has also added a standard of malaria treatment in the standard operating procedures (SOP). 
Based on the results of observations and interviews, the stakeholders involved are the Ministry of Health, the Lampung Provincial Health Office, the Pesawaran Regional Health Office, the Padang Cermin Public Health Center and Durian Village Government. Coordination is an important thing in the implementation of The Indonesian health program with a family approach (PIS-PK) in Pesawaran Region. Coordination is carried out in the form of providing education and training to health personnel. Aside from providing education and training, the Pesawaran Regional Health Office and Durian Village Government supervise the implementation of the Indonesian health program with a family approach $(P I S-P K)$. The variables of SOP and fragmentation significantly influence the implementation of policies concerning the health service program [32]. In the context of this research, the bureaucratic structure has been shown by the existence of standard operating procedure (SOP) and that SOP has a significant effect on the implementation of Indonesian health program with a family approach in Pesawaran Region. The standard operating procedure (SOP) is a guide for health personnel to carry out their duties in a consistent and measurable manner, because if there has not been a standard operating procedure (SOP), the division of tasks and implementation of the program will not be effective.

\section{CONCLUSION}

The implementation of human development policy in health sector through the Indonesian health program with a family approach $(P I S-P K)$ in Pesawaran Region, Lampung Province as a whole has been going well. The communication factor between policy implementers and beneficiaries is carried out through socialization and focus group discussions. The disposition factor is shown by technical support in the form of program implementation regulations at the local level and intensive support. The bureaucratic structure in implementing the program is already appropriate with the duties and functions of each agency. This is indicated by a clear division of tasks. The resource factor is an unsupportive factor because there are still limited health personnel and budget constraints in policy implementation. Limited health personnel and budget become the obstacles in the implementation of human development policies in health sector at Durian Village, Padang Cermin District, Pesawaran Regency. Based on these obstacles, the researchers give the recommendations to local government of Pesawaran Regency to add officers by selecting the officers and by prioritizing the expertise in the health sector and to add the health budget based on the priority scale, in the purpose to control the malaria.

\section{REFERENCES}

[1] Ministry of Health of the Republic of Indonesia, "Health Profile of Indonesia in 2013/Kementerian Kesehatan Republik Indonesia, "Profil Kesehatan Indonesia tahun 2013," [Online]. Available: https://pusdatin.kemkes.go.id/resources/download/pusdatin/profil-kesehatan-indonesia/profil-kesehatan-indonesia2013.pdf.

[2] Ministry of Health of the Republic of Indonesia, "Health Profile of Indonesia in 2015/Kementerian Kesehatan Republik Indonesia, "Profil Kesehatan Indonesia tahun 2015," [Online]. Available: https://www.pusdatin.kemkes.go.id/article/view/16091600001/profil-kesehatan-indonesia-tahun-2015.html.

[3] Teja and Mohammad, "Toodler Stunting in Indonesia and The Prevention," National Journal of Social Welfare, vol. 11 , no. 22 , pp. $15,2019$.

[4] Ministry of National Development Planning of the Republic of Indonesia, "A Two Years Trip of Nawa Cita in Central and Region," Journal of Simpul Perencana, vol. 29, no. 14, pp. 1, 2017.

[5] Ministry of Finance of the Republic of Indonesia, "State Budget of the Republic of Indonesia in 2015-2019/ Kementerian Keuangan Republik Indonesia, "Anggaran Pendapatan dan Belanja Negara Republik Indonesia tahun 2015-2019," [Online]. Available: https://www.kemenkeu.go.id/apbn2019.

[6] Ministry of Health of the Republic of Indonesia, "Strategic Plan of Ministry of Health for 2015-2019 (In Bahasa: Rencana Strategis Kementerian Kesehatan Republik Indonesia tahun 2015-2019)," [Online]. Available: https://promkes.net/2019/03/30/rencana-strategis-kementerian-kesehatan-tahun-2015-2019.

[7] P. Smoke, "Decentralization in Africa: Goals, Dimentions, Myths and Challenges," Public Administration and Development Journal, vol. 23, no. 1, pp. 7-16, 2003.

[8] P.G. Sow and V. Vinekar, "Effect of Public Librairies in the Attainment of Helath Millenium Development Goals in Senegal," International Journal of Public Health Science, vol. 7, no. 1, pp. 11-18, 2012.

[9] Agustina et al., "Implementation of Indonesian Health Program with Family Approach (PIS-PK) Using Contract Workers in Kulon Progo Regency 2018," Journal of Indonesian Health Policy, vol. 8, no. 3, pp. 104-112, 2019.

[10] Fatimah, D. Nur, "Implementation of Indonesian Health Program with Family Approach (PIS-PK) at Anjir Pasar Health Center, Barito Kuala District/Implementasi Program Indonesia Sehat dengan Pendekatan Keluarga di Puskesmas Anjir Pasar Kabupaten Barito Kuala,” Thesis, Universitas Gajah Mada, 2018.

[11] Rosalia, Feni and Dian Kagungan, "The Effect of Decentralization on Health Services: The experience of Pesawaran District, Lampung Province, Indonesia,” Medwell Journal, vol. 12, no. 11, pp. 2164-2168, 2017. 
[12] Uzhma et al., "Implementation of Indonesian Heath Program with a Family Approach for People with Severe Mental Disorders at the Community Health Center (Schizophrenia Case Study at the Kedungmundu Health Center, Semarang City)," Journal of Public Health, vol. 7, no. 2, pp. 1-7, 2019.

[13] Alam et al., "Organization Factors in the Performance Analysis of Indonesian Health Program Data Collection Employee in Public Health Center," Public Health Journal, vol. 7, no. 4, pp. 294-302. 2019.

[14] R. Ernawati and B. Adang, "Analysis of the Preparation for the Implementation of the Indonesian Health Program with a Family Approach (8 Indicator of Mental Health) in Depok City," Jurnal Kebijakan Kesehatan Indonesia, 2018.

[15] Pujosiswanto et al., "Affecting Factors Implementation of Indonesian Health Program with Family Approach (PISPK) at Polewali Mandar Public Health Center," Journal of Maritime Public Health, vol. 3, no. 1, pp. 123-134, 2020 .

[16] Karunianingsih et al., "Analysis of Factor Affecting the Implementation of Indonesia Health Card in Banjarsari District, Surakarta City," Journal off Public Policy and Management Review, vol. 9, no. 1, pp. 149-159, 2020.

[17] Astuti et al., "Analysis of Readiness for Financing Hypertension, Diabetes Mellitus and Mental Disorders in Supporting Indonesia Health Program with Family Approach in 2018-2020," Economic Health of Indonesia Journal, vol. 3, no. 1, pp. 135-146, 2018.

[18] Riswandha et al, "Performance of Surveillance of Indonesian Health Program at Public Health Center Regional Area of Jember District," Scientific Journal of Health Science, vol. 2, no. 1, pp. 23-27, 2020

[19] Statistic of Lampung Province, "Lampung Province in Figures 2019 (In Bahasa: Provinsi Lampung dalam Angka)," [Online]. Available: https://lampung.bps.go.id/publication/2019/08/16/801f3b93e755a417d7e80da5/provinsilampung-dalam-angka-2019.html.

[20] Ministry of Finance of the Republic of Indonesia, "Details of Non-Physical Special Allocation Funds of Province/Regency/City in State Budget 2019/Rincian Dana Alokasi Khusus Non-Fisik Provinsi, Kabupaten/Kota dalam APBN tahun 2019)," [Online]. Available: http://www.djpk.kemenkeu.go.id/wpcontent/uploads/2018/10/DAK-NONFISIK.pdf.

[21] Neuman and W. Lawrence, "Social Research Methods: Qualitative and Quantitative Approache," United States of America: Pearson Education, Inc, 2014.

[22] Edwards III, George C, "Implementing Public Policy," Washington DC: Congressional Quarterly Press, 1980

[23] Padang Cermin Health Center, "Health Profile of Padang Cermin Sub District in 2016/Profil Kesehatan Kecamatan Padang Cermin tahun 2016," 2016.

[24] Rubin and Allen et al., "Research Methods for Social Work," United States:Brooks/Cole, 2011.

[25] Ministy of Health of the Republic of Indonesia, "Guidelines of Indonesian Health Program with Family Approach 2016/Buku Pedoman Program Indonesia Sehat dengan Pendekatan Keluarga tahun 2016," 2016.

[26] Bryman and Alan, "Social Research Methods," New York: Oxford University Press, 2012.

[27] Neuman and W. Lawrence, "Social Research Methods: Qualitative and Quantitative Approaches," University of Wisconsin. Whitewater: Pearson Education, Inc number 3, 2000,

[28] Ganiem, L.M., "Medical Communication Theoretical and Practical Contexts," Depok: Prenada Media Group, 2018

[29] Government of Durian Village, "Profile of Durian Village, Padang Cermin District, Pesawaran Regency in 2019/Profil Desa Durian, Kecamatan Padang Cermin Kabupaten Pesawaran tahun 2019,” 2019.

[30] Ridwan et al., "Health Facility Services: Patient Satisfaction and Loyalty Factors," Medical Journal of Lampung University, vol. 4, no. 9, pp. 20-26, 2015.

[31] Subekti et al., "Influence Communication, Resources, Disposition and Structure of Bureau of Effectiveness Implementation of Operational Assitance Program School in the Elementary School Unit of Tambak District," The Indonesian Journal of Public Administration, vol. 3, no. 2, pp. 58-71, 2017.

[32] Maulidia and Fani Mega, "The Influence of Bureucratics Structure toward Policy Implementation of Health Services and Care for Adolescent Program," Health Scientific Journal, vol. 6, no. 2, pp. 183-192, 2017. 